\title{
Statyba
}

\section{DEFLECTION ESTIMATES OF REINFORCED CONCRETE BEAMS BY DIFFERENT METHODS}

\section{G. Kaklauskas PhD , D. Bačinskas \& R. Šitnkus}

To cite this article: G. Kaklauskas PhD , D. Bačinskas \& R. Šitnkus (1999) DEFLECTION ESTIMATES OF REINFORCED CONCRETE BEAMS BY DIFFERENT METHODS, Statyba, 5:4, 258-264, DOI: $10.1080 / 13921525.1999 .10531473$

To link to this article: https://doi.org/10.1080/13921525.1999.10531473

曲 Published online: 26 Jul 2012.

Submit your article to this journal

Llll Article views: 694 


\title{
DEFLECTION ESTIMATES OF REINFORCED CONCRETE BEAMS BY DIFFERENT METHODS
}

\author{
G. Kaklauskas, D. Bačinskas, R. Šimkus
}

\section{Introduction}

Civil engineers for analysis of reinforced concrete structures can choose between traditional code and modern numerical methods. Design codes of different countries [1-3] are often based on different assumptions and techniques for strength, cracking and deformation analysis. Although these methods ensure safe design, they do not reveal the actual stress-strain state of cracked structures and often lack physical interpretation. Numerical methods which were rapidly progressing within last decades are based on universal principles and can include all possible effects such as material non-linearities, concrete cracking, creep and shrinkage, reinforcement slip, etc, being responsible for complexity of this material. However, it must be said that the progress is mostly related to development of mathematical apparatus, but not material models, or in other words, the development was rather qualitative than quantitative.

Recently a new constitutive relationship for cracked tensile concrete based on smeared crack approach has been proposed [4] for deformation analysis of flexural reinforced concrete members. The relationship has been developed on a basis of a number of stress-strain curves for tensile concrete [4-6] obtained from beam tests reported in literature.

This work investigates accuracy of the proposed constitutive model. For that purpose, deflections have been calculated for a large number of experimental reinforced concrete beams reported by several investigators. Comparison with the experimental deflections and with estimates of four other methods has been performed.

\section{Deflection calculation methods}

In this section, five deflection estimation methods for flexural reinforced concrete members are briefly de- scribed. The first three methods chosen for comparison are the American Code (ACI Committee 318 [1]), the Eurocode EC2 [2], and the Russian (old Soviet) Code (SNiP 2.03.01-84 [3]) methods. Although these methods are based on different analytical approaches, all of them proved to be accurate tools for deflection assessment of members with high and average reinforcement ratios. It should be noted that these methods have quite a different level of complexity since the Russian Code method employs a great number of parameters and expressions whereas the ACI and EC2 methods are simple and include only basic parameters. The fourth method, here called as present analysis or layered method, is based on classical techniques of strength of materials extended to application of layered approach and full material diagrams. For modelling of behaviour of cracked tensile concrete, it employs the constitutive stress-strain relationship proposed by the first author [4]. The fifth method, based on regression analysis, has been developed by the third author [7].

ACI method [1]. The curvature of a reinforced concrete member is determined by the classical expression $\kappa=M / E I$ where $E I$ is the flexural stiffness. Branson [8] offered constant modulus of elasticity of concrete, $E_{c}$, for all loading stages, but varying moment of inertia, $I$. Thus, for the elastic stage, $I_{g}$ is written as for the gross concrete section ignoring reinforcement and for the load corresponding to the steel yielding $I_{c r}$ is calculated as for the cracked section. For loading points between the concrete cracking and yielding of the steel, Branson [8] derived the following equation to express the transition from $I_{g}$ to $I_{c r}$ that was observed in experimental data:

$$
I_{e}=\left(\frac{M_{c r}}{M}\right)^{3} I_{g}+\left[1-\left(\frac{M_{c r}}{M}\right)^{3}\right] I_{c r} .
$$


Here $M$ is the external moment; $M_{c r}=f_{r} I_{g} / y_{t}$ is the cracking moment; $f_{r}=0.643 \sqrt{f_{c}^{\prime}}[\mathrm{MPa}]$ is the modulus of rupture; $y_{t}$ is the distance from centroid to extreme tension fiber; $f_{c}^{\prime}$ is the compressive concrete cylinder strength.

Deflection for simple beams can be assessed from

$$
f=s \kappa l_{o}^{2},
$$

where $s$ is the factor depending on a loading case; $K$ is the curvature corresponding to the maximum moment, and $l_{0}$ is the beam span.

EC2 method [2]. In the EC2 model, a reinforced concrete member is divided into two regions: region $\mathrm{I}$, uncracked, and region II, fully cracked. In region I, both the concrete and steel behave elastically, while in region II the reinforcing steel carries all the tensile force on the member after cracking. Average curvature is expressed as

$$
\kappa=(1-\xi) \kappa_{1}+\xi \kappa_{2},
$$

where $\kappa_{1}$ and $\kappa_{2}$ correspond to the curvatures in regions I and II, respectively.

A distribution coefficient $\xi$ indicates how close the stress-strain state is to the condition causing cracking. It takes a value of zero at the cracking moment and approaches unity as the loading increases above the cracking moment. It is given by the relation

$$
\xi=\beta_{1} \beta_{2}\left(\sigma_{s r} / \sigma_{s}\right)^{2},
$$

where $\beta_{1}$ is a coefficient taking into account the bond properties of the reinforcement, it is taken 1 for deformed bars and 0.5 for plain (smooth) bars; $\beta_{2}$ is a coefficient assessing the duration and nature of the loading, it takes a value of 1 for short-term loads and 0.5 for sustained or cyclic loads; $\sigma_{s r}$ and $\sigma_{s}$ are the stresses in the tension steel calculated on the basis of a fully cracked section respectively under the cracking load and the load considered.

Russian (old Soviet) Code Method [3]. It is an empirical method based on a large number of experimental data which fundamentals were proposed by Murashev in 1950. The curvature of the cracked non-prestressed member is expressed through average strains of tensile reinforcement $\varepsilon_{s m}$ and compressive concrete at the extreme fiber $\varepsilon_{c m}$ :

$$
\kappa=\frac{\varepsilon_{s m}+\varepsilon_{c m}}{d},
$$

where

$$
\begin{gathered}
\varepsilon_{s m}=\psi_{s} \varepsilon_{s}=\psi_{s} \frac{\sigma_{s}}{E_{s}}=\psi_{s} \frac{M}{z A_{s} E_{s}}, \\
\varepsilon_{c m}=\psi_{c} \varepsilon_{c}=\psi_{c} \frac{\sigma_{c}}{v E_{c}}=\psi_{c} \frac{M}{\left(\xi+\varphi_{f}\right) E_{c} z b v d} .
\end{gathered}
$$

From (5), (6) and (7) the curvature relationship is as follows:

$$
\kappa=\frac{M}{z d}\left[\frac{\psi_{s}}{E_{s} A_{s}}+\frac{\psi_{c}}{\left(\xi+\varphi_{f}\right) v E_{c} b d}\right],
$$

where $M$ is the external moment; $z$ is the distance from the compressive to tensile resultant in a section; $d$ is the effective depth; $\psi_{s}$ is the ratio of the average steel strain $\varepsilon_{s m}$ and the steel strain in the cracked section $\varepsilon_{s} ; \psi_{c}$ is a similar factor defined for extreme compressive concrete fiber; $A_{s}$ is section area of tensile reinforcement; $E_{s}$ and $E_{c}$ are modulus of elasticity for steel and concrete respectively; $\xi$ is compression zone depth factor; factor $v$ assesses non-elastic strains in the concrete of the compression zone and factor $\varphi_{f}$ takes into account influence of the compressive reinforcement and compressive flange of $\mathrm{T}$-section.

In the development of this method, particular attention has been paid to deriving an empirical expression for factor $\psi_{s}$.

Present analysis method. This method is based on classical techniques of strength of materials extended to application of layered approach and full material diagrams. For modelling the behaviour of cracked tensile concrete, it employs results obtained by the first author [4]. It is based on the following approaches and assumptions: 1) assumption of 'plane sections'; 2) assumption of perfect bond between concrete and reinforcement; 3) smeared crack approach; 4) layered approach; 5) use of full stress-strain material relationships assumed to be constant for different layers of the same material.

According to the layered approach, the beam's crosssection is divided into a number of horizontal layers corresponding to either concrete or reinforcement. Each layer may have different material properties assumed to be constant over the layer thickness. Thickness of the reinforcement layer is taken from the condition of the equivalent area. For reinforcement material idealisation, a bilinear, trilinear (Fig 1, a) or more complex stress-strain 
relationship can be adopted. The stress-strain relationship for the compressive concrete has been assumed as in Fig 1, b where the ascending part has been taken according to the well-known expression [9]:

$$
\sigma_{c}=f_{c}^{\prime}\left[2 \frac{\varepsilon_{c}}{\varepsilon_{0}}-\left(\frac{\varepsilon_{c}}{\varepsilon_{0}}\right)^{2}\right] ;\left(\varepsilon_{0}=2 f_{c}^{\prime} / E_{c}\right)
$$

The authors presently are working on developing a new stress-strain relationship for cracked tensile concrete. This analysis employs the shape of $\sigma_{t}-\varepsilon_{t}$ relationship
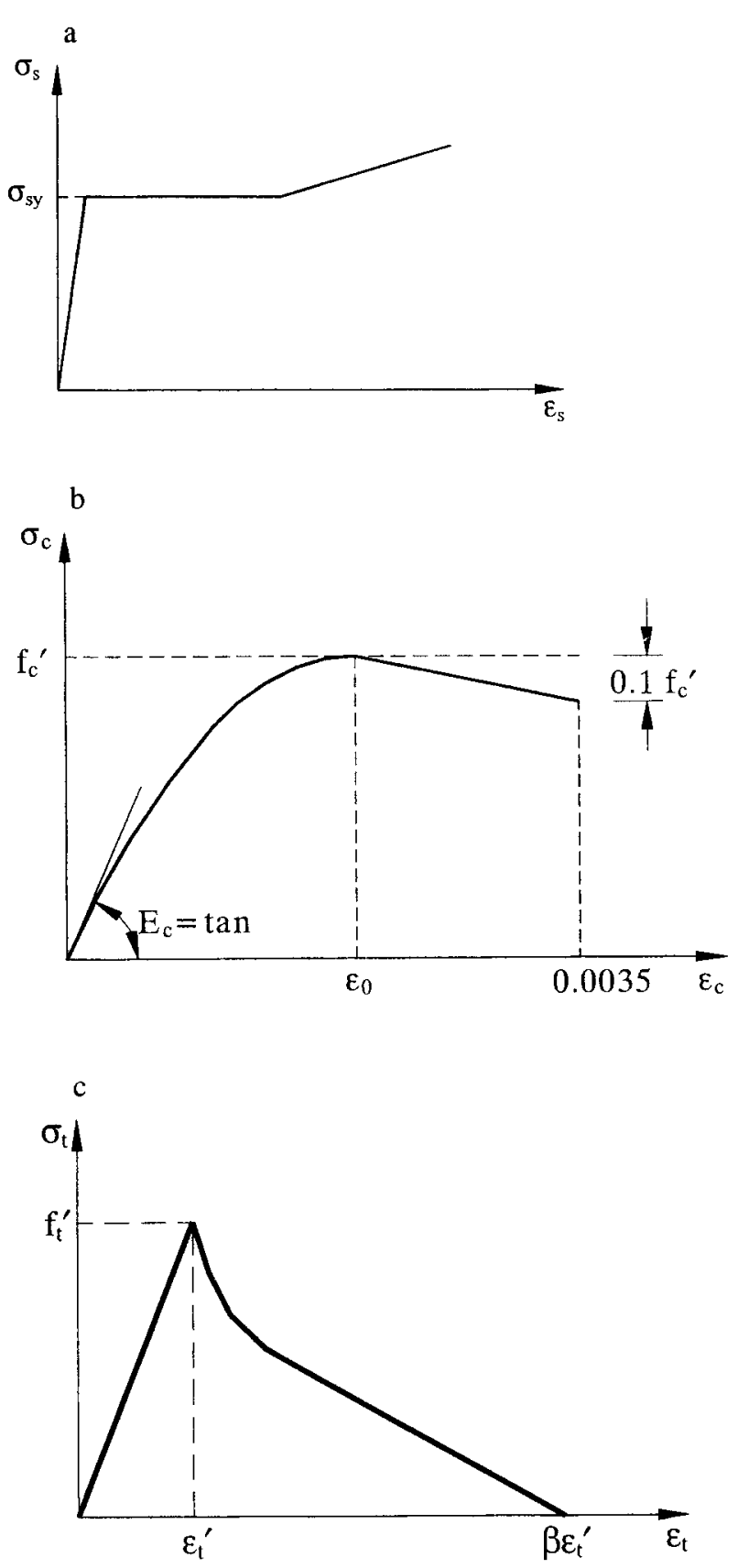

Fig 1. Stress-strain relationships: $a$ - reinforcement; $b$ - compressive concrete; $\mathrm{c}$ - tensile concrete
[4] shown in Fig 1, $\mathrm{c}$ the descending part of which has the expression:

$$
\sigma_{t}=a f_{t}^{\prime}\left(1-\frac{\overline{\varepsilon_{t}}}{\beta}-\frac{1+\beta(1-a) / a}{\beta\left(\overline{\varepsilon_{t}}\right)^{b}}\right),
$$

where

$$
\overline{\varepsilon_{t}}=\frac{\varepsilon_{t}}{\varepsilon_{t}^{\prime}} ; \varepsilon_{t}^{\prime}=\frac{f_{t}^{\prime}}{E_{c}}
$$

In present analysis, tensile strength of concrete is taken as [3]:

$$
f_{t}^{\prime}=0.23 \sqrt[3]{R_{15}^{2}} \quad[\mathrm{MPa}]
$$

where $R_{15}$ is $150 \mathrm{~mm}$ cube compression strength.

Due to present state of knowledge [4], parameters $a$ and $b$ were assumed as 0.625 and 1 respectively. Then Eq (10) acquires the following shape:

$$
\sigma_{t}=0.625 f_{t}\left(1-\frac{\overline{\varepsilon_{t}}}{\beta}-\frac{1+0.6 \beta}{\beta \overline{\varepsilon_{t}}}\right) \text {. }
$$

Parameter $\beta$ defining the length of extension of $\sigma_{t}-\varepsilon_{t}$ curve (see Fig 1, c) is equal to $\overline{\varepsilon_{t}}$ corresponding to zero stress. According to [4] $\beta$ is taken as

$$
\begin{gathered}
\beta=32.8-27.6 p+7.12 p^{2}, \\
\beta=5, \text { if } p \geq 2 \%,
\end{gathered}
$$

where $p$ is reinforcement percentage.

A computer program has been developed for assessment of average stress and strain state at any point of the beam as well as for calculation of curvatures and deflections. For a given external moment, the computation is performed in iterations by the following steps:

1. In the first iteration, elastic material properties are assumed for all the layers.

2. Geometrical characteristics are calculated for the transformed cross-section.

3. Curvature of the section is calculated from the expression:

$$
\kappa=\frac{M}{(E I)_{t r}}
$$

where $(E I)_{t r}$ is the flexural stiffness of the transformed cross-section.

4. Longitudinal strain at every layer $i$ is taken as

$$
\varepsilon_{i}=\kappa y_{i},
$$


where $y_{i}$ is the distance of $i$ layer from the centroid of the transformed cross-section.

5. For the assumed material diagrams (Fig 1), stress $\sigma_{i}$ corresponding to strain $\varepsilon_{i}$ is obtained. A secant deformation modulus $\bar{E}_{i}=\sigma_{i} / \varepsilon_{i}$ is determined.

6 . Values of the obtained secant deformation modulus $\overline{E_{i}}$ for every layer are compared with the previously assumed or computed ones. If the agreement is not within the assumed error limits, a new iteration is started from step 2.

7. After convergation of deformation modulus $\vec{E}_{i}$ for all the layers, final values of strains, stresses and curvature are assessed. For deflection calculation which is performed by Mohr's integral technique, analogous computations are carried out for other sections of the beam.

Shimkus method [7]. The proposed curvature relationship is based on regression analysis made for 583 experimental beams:

$$
\kappa=\frac{a M_{u}\left(\frac{M}{M_{u}}-b\right)}{E_{c} l_{t r}},
$$

where parameters $a$ and $b$ for non-prestressed members

$$
\begin{gathered}
a=3.70 e^{0.19(\alpha-1.75)-2.5\left(\mu \alpha_{s}-0.134\right)}, \\
b=0.085\left(\ln \alpha+\sqrt{(\ln \alpha)^{2}+2.44} .\right. \\
\alpha=\frac{I_{t r}}{n A_{s} h^{2}} .
\end{gathered}
$$

Here $M$ and $M_{u}$ are the external and the ultimate bending moments; $E_{c}$ is the modulus of elasticity of concrete; $I_{t r}$ is the moment of inertia of the transformed section; $\mu=\frac{A_{s}}{b d}$ is the reinforcement percentage; $n=\frac{E_{s}}{E_{c}}$ is the modular ratio; $A_{s}$ is the section area of tensile reinforcement; $h$ is the section depth.

\section{Comparison of deflections assessed by different methods with test results}

This section compares mid-span deflections assessed by five methods with test data of 76 simple beams reported by five [10-14] investigators. Main characteristics of the beams indicating variations in span, cross-section parameters and concrete strength are presented in $\mathrm{Ta}$ ble 1. Most of the beams had a rectangular, but some an inverted $\mathrm{T}$ section. All the beams were subjected to a short-term loading of two concentrated forces which divided the beam into three equal pieces.

Experimental data of Nemen [10], Artiomjev [11] and Jokubaitis [12] can be categorised as beams having average and high reinforcement ratios. However, experimental data of Figarovskij [13] and Gushcha [14] should be dealt separately, since most of the beams had a very low reinforcement ratio. Lightly reinforced beams is an extreme case of bending analysis, because the stress-strain state as well as curvatures and deflections are significantly influenced by effects of cracked tensile concrete. Since tensile strength is a highly dispersed value, it is very difficult to predict deflections accurately at loads just above the cracking loads, particularly for lightly reinforced members.

Deflections for beams were calculated at five moment levels, ie $0.4,0.55,0.6,0.7$ and 0.8 of $M_{y}$ which is the yielding moment. The moments smaller than the cracking moment were excluded from the analysis. However, for most of the Figarovskij beams [13] only one or two experimental deflection points corresponding to the above-indicated moment levels were available. This was due to two reasons: 1) tests of many beams, particularly those later on subjected to long-term loading, were terminated prior to moment $0.8 M_{y} ; 2$ ) for some beams, particularly those with very small reinforcement ratios, the experimental cracking moment, $M_{c r, \exp }$, exceeded $0.4 M_{y}$. For these reasons, deflections for the Figarovskij beams were calculated at five moment levels equally spaced between moments $1.1 M_{c r \text { exp }}$ and $M_{\max \text {,exp }}$ where $M_{\max , \exp }$ is the maximum moment reached in the experiment. The lower limit assured comparison of deflections for the cracked stage.

Accuracy of predictions made by each method has been assessed using basic statistical parameters such as mean value and standard deviation calculated for relative deflections $f_{t h} / f_{\text {exp }}$. Table 2 contains the statistical parameters for the following data: 1) for each of the author; 2) data of Nemen, Artiomjev and Jokubaitis, ie beams having average and high reinforcement ratios (Table 1); 3) data of Figarovskij and Gushcha, ie beams having small and average reinforcement ratios, and 4) for total data. The following observations can be made from the results presented in Table 2 .

For beams with average and high reinforcement ratios (data of Nemen, Artiomjev and Jokubaitis), accurate 
Table 1. Main characteristics of beams

\begin{tabular}{|l|c|c|c|c|c|c|}
\hline Author & $\begin{array}{c}\text { Total number of } \\
\text { beams }\end{array}$ & $\begin{array}{c}\text { Span } \\
{[\mathrm{m}]}\end{array}$ & $\begin{array}{c}\text { Height } \\
{[\mathrm{mm}]}\end{array}$ & $\begin{array}{c}\text { Width } \\
{[\mathrm{mm}]}\end{array}$ & $\begin{array}{c}\text { Reinforcement ratio } \\
{[\%]}\end{array}$ & $\begin{array}{c}100 \mathrm{~mm} \text { cube } \\
\text { strength }[\mathrm{MPa}]\end{array}$ \\
\hline Artiomjev & 15 & 3.00 & $250-264$ & $176-187$ & $0.801-0.909$ & $18.84-53.40$ \\
\hline Nemen & $18\left(5^{*}\right)$ & 1.80 & $180-185$ & $100-187$ & $1.336-2.910$ & $30.00-45.00$ \\
\hline Jokubaitis & 8 & 1.80 & 180 & 100 & $0.800-0.950$ & $53.50-64.80$ \\
\hline Figarovskij & $33\left(9^{*}\right)$ & 3.00 & $248-254$ & $179-181$ & $0.160-1.260$ & $10.50-36.00$ \\
\hline Gushcha & 4 & 3.60 & $306-312$ & $133-162$ & $0.279-0.970$ & $30.00-40.80$ \\
\hline
\end{tabular}

* - a number of beams of $\mathrm{T}$ or I - sections out of the total number of beams

Table 2. Statistical parameters for relative deflections, $f_{t h} / f_{\exp }$, estimated by different methods

\begin{tabular}{|l|c|c|c|c|c|c|c|c|c|c|}
\hline \multirow{2}{*}{$\begin{array}{c}\text { Author of } \\
\text { experiment }\end{array}$} & \multicolumn{2}{|c|}{ ACI } & \multicolumn{2}{c|}{ EC2 } & \multicolumn{2}{c|}{ Russian Code } & \multicolumn{2}{c|}{ Present analysis } & \multicolumn{2}{c|}{ Shimkus method } \\
\cline { 2 - 13 }$y$ & Mean & Stand. & Mean & Stand. & Mean & Stand. & Mean & Stand. & Mean & Stand. \\
\hline Artiomjev & 0.944 & 0.074 & 0.888 & 0.071 & 1.011 & 0.063 & 0.975 & 0.061 & 0.838 & 0.140 \\
\hline Nemen & 1.046 & 0.088 & 0.971 & 0.080 & 1.027 & 0.115 & 1.007 & 0.092 & 1.048 & 0.089 \\
\hline Jokubaitis & 0.992 & 0.095 & 0.963 & 0.089 & 1.012 & 0.051 & 0.991 & 0.069 & 0.676 & 0.169 \\
\hline Figarovskij & 1.115 & 0.266 & 1.230 & 0.320 & 1.003 & 0.204 & 0.957 & 0.168 & 1.037 & 0.295 \\
& $(1.064)$ & $(0.219)$ & $(1.136)$ & $(0.233)$ & $(0.998)$ & $(0.164)$ & $(0.945)$ & $(0.145)$ & $(1.014)$ & $(0.242)$ \\
\hline Gushcha & 0.791 & 0.177 & 0.866 & 0.102 & 0.883 & 0.154 & 0.890 & 0.122 & 0.648 & 0.213 \\
\hline Total $(1+2+3)$ & 0.997 & 0.120 & 0.937 & 0.111 & 1.015 & 0.116 & 0.989 & 0.107 & 0.913 & 0.192 \\
\hline Total (4+5) & 1.079 & 0.276 & 1.190 & 0.324 & 0.990 & 0.202 & 0.950 & 0.165 & 0.994 & 0.312 \\
& $(1.027)$ & $(0.233)$ & $(1.100)$ & $(0.238)$ & $(0.983)$ & $(0.167)$ & $(0.938)$ & $(0.144)$ & $(0.965)$ & $(0.269)$ \\
\hline Total & 1.037 & 0.214 & 1.058 & 0.270 & 1.003 & 0.164 & 0.971 & 0.139 & 0.952 & 0.260 \\
& $(1.010)$ & $(0.178)$ & $(1.007)$ & $(0.195)$ & $(1.001)$ & $(0.141)$ & $(0.967)$ & $(0.127)$ & $(0.935)$ & $(0.230)$ \\
\hline
\end{tabular}

deflection predictions have been made by the present analysis, Eurocode, Russian Code, and ACI methods yielding $10.7,11.1,11.6$ and $12.0 \%$ of standard deviations for relative deflections, $f_{t h} / f_{\exp }$. However, predictions for lightly reinforced beams (data of Figarovskij and Gushcha) have been far less accurate giving standard deviation of $16.5,32.4,20.2$ and $27.6 \%$ for the respective methods. The shocking value of $32.4 \%$ for the EC2 method can be explained by inaccuracies of the deflection estimates made for the Figarovskij beams at loads just above the cracking loads. The EC2 method underestimates the cracking moment and often significantly overestimates the corresponding deflection in some cases yielding an error of over $100 \%$. Elimination of deflection points of Figarovskij data corresponding to $1.1 M_{c r, \exp }$, lead to improved results (particularly for the EC2 method) given in parentheses in Table 2 .

Although as it is shown in Table 2 some better agreement between the calculated and experimental deflections in terms of standard deviation for the total data has been achieved for the present technique and the Russian Code (13.9 and $16.4 \%$ respectively), it should be kept in mind that experimental data of Figarovskij and Artiomjev were used in developing the Russian Code method and the experimental data of 9 beams from the Figarovskij tests were employed for developing the material model of tensile concrete in the present analysis [Eq (13)]. Besides, these two methods use similar empirical material characteristics for concrete (compressive and tensile strength and modulus of elasticity) to those used by the experimenters (all from the former USSR). Furthermore, the main concern of the Code methods is a correct deflection estimate at the service load while deflections at other loads are of lesser importance. All this indicates that under different conditions of comparison, the results might be slightly different from those presented in Table 2 .

The Shimkus method, based on regression analysis principles, makes 19.2 and $31.2 \%$ error for members with large and small amounts of reinforcement respectively. As 
the most simple, this method can be used for cases when high deflection estimation accuracy is not required.

\section{Conclusions}

Accuracy of the proposed constitutive relation for tensile concrete in flexure has been investigated by means of deflection estimation of 76 experimental RC beams. Comparison with the experimental deflections at five load levels and with estimates of four other methods has been performed.

For beams with average and high reinforcement ratios (data of Nemen, Artiomjev and Jokubaitis), accurate deflection predictions have been made by the present analysis, Eurocode, Russian Code, and ACI methods yielding $10.7,11.1,11.6$ and $12.0 \%$ of standard deviations for relative deflections, $f_{t h} / f_{\text {exp }}$. However, as expected predictions for lightly reinforced beams (data of Figarovskij and Gushcha) have been far less accurate giving standard deviation of $16.5,32.4,20.2$ and $27.6 \%$ for the respective methods. These risen inaccuracies are related to increased influence of tensile concrete which is a highly dispersed value. The EC2 method underestimates the cracking moment and often significantly overestimates the corresponding deflection in some cases yielding an error of over $100 \%$.

Due to more accurate deflection estimates for lightly reinforced members, the best agreement in terms of standard deviation assessed for the total data has been achieved for the present analysis and the Russian Code methods (13.9 and $16.4 \%$ respectively).

The Shimkus method which is the most simple among the five methods gives reasonable results, particularly for members with higher reinforcement ratio. This method can be used for cases when high deflection estimation accuracy is not needed.

\section{References}

1. ACI Committee 318. Building Code Requirements for Reinforced Concrete and Commentary (ACI 318-89/ACl 318R-89). Detroit: American Concrete Institute (ACI), 1989. $353 \mathrm{p}$

2. ENV 1992-1-1.Eurocode 2: Design of Concrete Structures - Part 1: General rules and rules for buildings. Brussels, 1992. $114 \mathrm{p}$

3. СНиП 2.03.01-84*. Бетонные и железобетонные конструкции. М.: Госстрой СССР. $1989.80 \mathrm{c}$.

4. G. Kaklauskas. Universal Constitutive Model for Flexural Reinforced Concrete Members. Internal Report, Academy of Sciences of Lithuania, Vilnius, 1999.
5. G. Kaklauskas. Average Stress-Strain Relations for Concrete from Experimental Moment-Strain Diagrams of Beams and Slabs // Statyba, Vol IV, No 2. Vilnius: Technika, 1998, p. 92-100.

6. G. Kaklauskas, J. Ghaboussi, and X. Wu. Neural Network Modelling of Tension Stiffening Effect for R/C Flexural Members // Proceedings, EURO-C 1998-Computational Modelling of Concrete Structures, Badgastein, Austria, March 31 - April 3, 1998, p. 823-832.

7. R. Šimkus. Naujas metodas lenkiamų gelžbetoninių elementų kreiviui skaičiuoti // Konferencijos „Statybinès konstrukcijos: kūrimas ir stiprinimas", ivykusios Vilniuje 1998 m. lapkričio $20 \mathrm{~d}$., pranešimy medžiaga. V.: Technika, 1998, p. 32-37.

8. D. E. Branson. Deformation of Concrete Structures. New York: McGraw Hill Book Company, 1977. 546 p.

9. E. Hognestad. A Study of Combined Bending and Axial Load in Reinforced Concrete Members. Biulletin 399. University of Illinois Engineering Experiment Station, Urbana, Ill., 1951. $128 \mathrm{p}$.

10. В. Н. Немен. Экспериментальное исследование деформаций изгибаемых железобетонных элементов при действии статических нагрузок: Дис. ... канд. техн. наук. Каунас, 1967.

11. В. П. Артемьев. Исследование прочности, трещиностойкости и жесткости обычных и предварительно напряженных железобетонных балок: Дис. ... канд. техн. наук. Москва, 1959.

12. V. Jokūbaitis. Désningu ir atsitiktiniu plyšių itaka armuotu betoninių sijų deformacijoms, veikiant trumpalaikei apkrovai: Disertacija technikos mokslų kandidato laipsniui igyti. Kaunas, 1967.235 p.

13. В. В. Фигаровский. Экспериментальное исследование жесткости и трещиностойкости железобетонных изгибаемых элементов при кратковременном и длительном действии нагрузок: Дис. ... канд. техн. наук. Москва, 1962

14. Ю. П. Гуща. Исследование изгибаемых железобетонньх элементов при работе стержневой арматуры в упруго-пластической стадии: Дис. ... канд. техн. наук. Москва, 1968

Itteikta 19990929

\section{GELŽBETONINIŲ SIJU ILINKIU VERTINIMAS IVAIRIAIS METODAIS}

\section{G. Kaklauskas, D. Bačinskas, R. Šimkus}

Santrauka

Neseniai buvo pasiūlyta supleisejusio tempiamo betono ittempių-deformacijų priklausomybè [4] lenkiamujų gelžbetoninių elementų deformacijoms apskaiciuoti. Ši priklausomybè buvo išvesta, taikant novatorišką metodą [4-6], kuriuo iš eksperimentinių lenkiamų gelžbetoninių sijų momentụ-kreivių ir (arba) momentų-deformacijų diagramų nustatoma visa tempiamo betono vidutinių itempių-deformacijų diagrama, iskaitant ir jos krintančiaja dali. Apdorojus ivairiu autoriu eksperimentais gautas tempiamo betono itempių-deformaciju diagramas, buvo pasiūlyta minètoji medžiagos priklausomybè, aprašyta (13) priklausomybe.

Šio darbo tikslas yra patikrinti pasiūlytosios priklausomybès tikslumą. Ją taikant dideliam eksperimentinių gelžbetoninių sijų (išbandytų kelių tyrinètojų) skaičiui buvo apskaičiuoti ịlin- 
kiai ir palyginti su kitų žinomụ analitinių metodų apskaičiavimo rezultatais.

Trumpai apibūdinami penki lenkiamujjų gelžbetoninių elementu jlinkių skaičiavimo metodai. Pirmieji trys - tai ameri kiečių [1], Euronormų [2] bei Lietuvoje galiojančių normų [3] metodai. Ketvirtasis, vadinamasis sluoksniu metodas, yra pagristas: 1) klasikinemis medžiagu atsparumo formulèmis, 2) sluoksnių metodu, 3) išsamiu medžiagų diagramų taikymu bei 4) iteraciniu skaičiavimu. Šiame metode supleišjejusio tempiamo betono darbo modeliavimui taikoma šio straipsnio pirmojo autoriaus pasiūlyta priklausomybe (13). Penktasis, regresinès analizès metodas [7], yra pasiūlytas sio straipsnio trečiojo autoriaus.

Pateikiami svarbiausi 76 gelžbetoninių sijų, 5 autorių išbandytu trumpalaike apkrova, duomenys ( 1 lent.). Visais minètais metodais kiekvienai sijai penkiuose apkrovos lygiuose buvo apskaičiuoti illinkiai, kurie buvo palyginti su eksperimentu rezultatais.

Vertinant tiksluma, kiekvienam skaičiavimo metodui buvo nustatyti tokie svarbiausi statistiniai dydžiai kaip vidurkis bei vidutinis kvadratinis nuokrypis. Šie statistiniai parametrai buvo gauti santykiniams ilinkiams $f_{t h} / f_{\text {exp }}$, kur $f_{\text {th }}$ yra apskaičiuotas, o $f_{\exp }$ - eksperimentinis įlinkis. Skaiciavimo rezultatai parodè ( 2 lent.), kad pirmieji keturi metodai pakankamai tiksliai ivertina vidutiniškai ir stipriai armuotų sijų Łlinkius (gautas vidutinis kvadratinis nuokrypis yra 10-12\%). Tačiau silpnai armuotoms sijoms, kurių ilinkiams tempiamo betono darbas turi didelę itaką gauta daug didesnè paklaida. Skaičiuojant sluoksniu metodu bei Lietuvoje galiojančic normu, amerikiečių normu ir Euronormy metodais gautas atitinkamai 16,5, $20,2,27,6$ ir $32,4 \%$ vidutinis kvadratinis nuokrypis. Euronormose didelè paklaida daroma skaičiuojant illinkius, kuriuos atinkantys momentai nedaug viršija supleišèjimo momenta. Bendrai ivertinant visas sijas, geriausi rezultatai gauti skaiciuojant sluoksniu ir Lietuvoje galiojančiu normų metodais (vidutinis kvadratinis nuokrypis atitinkamai 13,9 ir 16,4\%). Kartu būtina pažymeti, kad Artiomjevo ir Figarovskio eksperimentinių siju duomenys ( 1 lent.) buvo panaudoti, kuriant Lietuvoje galiojančiu normu metodą o pastarojo autoriaus sijų duomenys - ir išvedant (13) priklausomybę. Be to, pagal šiuos du metodus betono charakteristikoms (stiprumas tempiant ir gniuždant bei tamprumo modulis) nustatyti taikomos panašios empirinès for- mules, kokias taikè ir eksperimentu autoriai (visi iš buvusios Sovietų Sajungos). Pagaliau pagal normų metodus pagrindinis demesys skiriamas ilinkiams, atitinkantiems norminę apkrova. apskaičiuoti, o kitų ilinkių vertinimas gali būti ne toks tikslus. Tai gali reikšti, kad, esant kitokioms palyginimo salygoms, rezultatai galètụ būti kiek kitokie.

Vertinant stipriai ir silpnai armuotų sijų ilinkius Šmkaus pasiūlytu metodu [7], gautas atitinkamai 19,2 ir $31,2 \%$ vidutinis kvadratinis nuokrypis. Šis metodas, kaip paprasčiausias iš visu minètų gali büti taikomas tais atvejais, kai tikslus ilinkiu vertinimas nèra bütinas.

Gintaris KAKLAUSKAS. PhD, Senior Researcher and Associate Professor. Dept of Reinforced Concrete Structures, Vilnius Gediminas Technical University, Sauletekio al. 11, 2040 Vilnius, Lithuania.

A graduate of Vilnius Civil Engineering Institute (presently Vilnius Gediminas Technical University, VGTU) (1982, civil engineer). PhD (1990). Research visits: Aalborg University (Denmark, 1991), University of Glamorgan (UK, 1994/1995/1998), University of Illinois, Urbana-Champaign (USA, 1996). Author and co-author of 2 monographs, 1 invention and a number of papers. Research interests: development of constitutive relationships for concrete and numerical simulation of reinforced concrete structures.

Darius BAČINSKAS. PhD student. Dept of Reinforced Concrete Structures, Vilnius Gediminas Technical University, Saulètekio al. 11, 2040 Vilnius, Lithuania.

MSc (1997, civil engineer) at Vilnius Gediminas Technical University. Co-author of 2 research papers. Research interests: deformation of reinforced concrete structures.

Rimantas SIMKUS. Researcher. Institute of Building and Architecture. Tunelio 60, 3000 Kaunas, Lithuania.

A graduate of Kaunas Politechnic Institute (presently Kaunas University of Technology) (1973, civil engineer). With some interruptions works at research Institute of Building and Architecture in Kaunas. Author and co-author of a number of papers. Research interests: development of analytical and statistical methods for deflection calculation of reinforced concrete flexural structures. 